\title{
RELATIONSHIP BETWEEN SCHOOL ADMINISTRATORS' COMPETENCE BELIEFS ON INNOVATION MANAGEMENT AND THEIR LEADERSHIP BEHAVIORS
}

\author{
DOI: 10.17261/Pressacademia.2017.480
}

RJBM- V.4-ISS.2-2017(17)-p.236-246

\author{
Hanifi Parlar ${ }^{1}$ \\ ${ }^{1}$ Istanbul Commerce University, Istanbul, Turkey. hanifiparlar@mail.com
}

\section{To cite this document}

Parlar, H., (2017). Relationship between school administrators' competence beliefs on innovation management and their leadership behaviors. Research Journal of Business and Management (RJBM), V.4, Iss.2, p.236-246.

Permemant link to this document: http://doi.org/10.17261/Pressacademia.2017.480

Copyright: Published by PressAcademia and limited licenced re-use rights only.

\begin{abstract}
Purpose- In this study, it was aimed to reveal the relationship between school principals' competence beliefs on innovation management and their leadership behaviors.

Methodology- Teachers working at the high schools located in Üsküdar district of Istanbul province constituted the sample of the study that was carried out with the relational screening method, one of quantitative research methods. In the study, data were collected with the school principals' leadership style inventory and innovation management at schools scale and analyzed using the SPSS program. In the analysis of the data, descriptive statistics such as arithmetic mean and standard deviation were calculated, and the t-test, one-way analysis of variance (ANOVA), Scheffe's test, Pearson Product-Moment Correlation Coefficient and simple linear regression analysis were used.

Findings- According to the research results, it was observed that teachers' competence beliefs on innovation management were not significantly different between male and female teachers by the gender variable and age variable. On the other hand, the organizational culture and structure sub-dimension scores were in favor of teachers aged 40 and older.It was observed that they were not significantly different between teachers with different seniority levels by the seniority variable and between teachers with different educational levels by the educational status variable.

Conclusion- It was determined that innovation management competencies consisting of four different sub-dimensions had a significant predictive effect on transactional leadership behaviors consisting of two sub-dimensions and transactional management sub-dimensions consisting of five sub-dimensions.
\end{abstract}

Keywords: School administrator, innovation management, leadership behaviors

JEL Codes: G10, G32

\section{INTRODUCTION}

When innovation is considered as producing new, useful and creative ideas and putting them into practice, it is possible to define innovation in education as "a process and outcome that direct innovation and creativity in the system by taking into account all elements of the educational process, develop creativity, apply contemporary innovations and developments in the educational processes within the administration and supervision of the educational institution, transform practical knowledge into practice and control its outputs". Within the scope of innovation, educational organizations such as schools, universities and teaching centers may offer applications such as new products and services such as a new curriculum, new processes in the delivery of services, the use of information and communication technologies in e-learning, the use of information and communication technologies in communication with students and families. These new applications are trying to develop-improve the educational service in one way or another. Accordingly, innovations in education should be regarded as the 'developments (improvements)'. 
The desire of organizations to achieve their objectives effectively has brought out the need for leadership. Behavioral scientists have tried to determine which characteristics, skills, behaviors and power supplies a leader, who has achieved the group objectives and can affect the follower, has. At the beginning of the twentieth century, leadership studies focused on the characteristics approach. There were very few topics that were more controversial than leadership traits and qualities. These theories were based on the claim that the qualities of leaders were different from those who were not leaders. An attempt to compare the characteristics of successful and unsuccessful leaders was made in trait theories. The distinctive traits of leaders were revealed in these comparisons made. Effective leaders were thought to be different from ineffective leaders in terms of their interest, ability and personality traits.

School leaders are leaders of change and innovation in schools. The approach of school principals to innovation management and the leadership behaviors that they demonstrate accordingly affect the teachers positively or negatively. Positively affected teacher plays a key role in student happiness and success. Based on this general framework, to reveal the relationship between the competence beliefs of school administrators on innovation management and their leadership behaviors can help to increase the educational quality of schools. It is thought by the researcher that the competence beliefs of school administrators on innovation management may increase as their leadership behaviors increase. Thus, it is possible to make deductions on the development of innovation management and transformational leadership behaviors. With this approach, in this study, it was aimed to reveal the relationship between school principals' competence beliefs on innovation management and their leadership behaviors.

\section{LITERATURE REVIEW}

\subsection{Leadership and Transformational Leadership}

School leadership is the act of being able to affect and direct the others to accomplish the common objectives in relation to the school (Leithwood and Reihl, 2005). School leadership requires taking responsibility for setting goals, ensuring adaptation and unity, a value-based management, creating opportunities, modeling and inspecting (Sergiovanni, 1996). In the literature, school leadership can be addressed within the context of different types of leadership. Instructional Leadership, managerial leadership, transformational leadership, moral and authentic leadership, distributed leadership, teacher leadership, system leadership and contingent leadership types are intensively discussed types of leadership (Bush \& Glover, 2014). It can be said that the efforts to educate students as more qualified individuals are at the base of the fact that school leadership is addressed within the context of different leadership types.

The responsibilities and duties of school administrators have undergone changes throughout the historical process. While school administrators were more focused on technical and humanitarian aspects in organizations in the 1950s, they were less focused on studies on educational quality and student outcomes. However, the subsequent developments in the school environment made it necessary to focus more on the educational aspect along with the administrative management of the school (Sergiovanni, 2001). Increased expectations from the school, as well as the changes in areas different from the school, have been effective on the emergence of managerial behaviors aimed at providing the educational needs of students. In this process, firstly school administrators had the role of principal teacher. Then, they passed to the role of institutional administrators. However, dropout rates at schools, cultural problems, the belief that every student was capable of learning and expectations for accountability began to increase. The transition to school leadership, which is a sense of leadership aimed at increasing the quality in the nature of education, was ensured with these processes (Wilmore, 2002). On the other hand, the concept of school leadership underwent a change towards "educational administration", "educational management" and "educational leadership" (Gunter, 2004). It is observed that the concepts of educational leadership and school leadership are used in place of each other in the literature (e.g., Leithwood and Reihl, 2005; Waters, Marzona and McNulty, 2003). It can be said that the fact that school administration began to be discussed within the scope of school leadership, and the increase in expectations about student learning resulted from the rapid reflection of changes in different areas on the school community. Furthermore, it can also be stated that school leadership has continued to be discussed through different perspectives.

There are some leadership behaviors that school leaders should show. Sergiovanni (1984) states that school administrators should have technical, humanitarian, educational, symbolic and cultural leadership skills. According to Bolman and Deal (1991), school administrators' skills can also be discussed within the frame of organizational models called human resources, bureaucratic, symbolic and political model. Effective school leaders carry out the sense of leadership and administration collectively, act as experts who ensure the development of teachers and students, have values and vision for school development and put forward studies supporting the development of teachers (Harris, Day and Hadfield, 2003). On the other hand, according to the results obtained from different studies, school leaders have some effective common leadership behaviors. These are creating a vision for the school, curriculum programming and evaluation, making good use of school resources, establishing a culture of support at school, providing an environment in which communication is open, recognizing the school community, being change agents, sharing the authority, dealing with administrative issues effectively, ensuring the professional development of teachers and creating high expectations (Krüger, 2009; Leithwood 
and Montgomery, 1982; Marzano, Waters and McNulty, 2005; Murphy, Elliot, Goldring and Porter, 2010; Robinson, Hohepa and Lloyd, 2007; Robinson, Lloyd,\& Rowe, 2008). Based on the results of these studies, student learning and school development-oriented studies are expected to be discussed within the scope of school leadership. In this regard, it can be stated that it is important for school leaders to have the qualifications to comprehend the system as a whole, such as vision, program studies, cooperation among stakeholders for the realization of the technical nature of the school.

The leadership behaviors of school administrators are discussed in the present study (Ata, 2015). In this context, the leadership behaviors that can be exhibited are as follows: (i) to create a learning vision and to carry out studies for practice, (ii) to develop a school culture and curriculum for the development of student learning and school staff, (iii) to review the administration and operational procedures to provide a positive learning environment, to create an environment in which the authorities are shared, and to provide resource, (iv) to cooperate with the school's different stakeholders and to establish and maintain productive relationships with them, and to use them for school, $(v)$ to behave to ensure the academic and social success of each student by acting in an ethical manner, and to give particular importance to democratic values, (vi) to present a number of new leadership strategies by regarding the social, political, economic, legal and cultural variables in the social structure as a whole. Based on these standards and other research findings above, it can be stated that effective school leadership behaviors refer to the behaviors of school administrators to increase the quality of education.

Burns (1978) proposed the transformational and transactional leadership theories, based relationships between the leader and the follower on a moral principles system and developed rules regarding the nature of morally good leadership. Values such as responsibility, honesty, truthfulness and keeping word on which transactional leadership is based refer to the instrumentality of an action. Transformational leadership is related to objective values such as freedom, justice, and equality (Ciulla, 1995). Bass (1999) further developed the transformational and transactional leadership approaches. He determined the dimensions of transformational leadership as idealized influence (charisma), inspirational motivation, intellectual stimulation and individualized consideration (Bass \& Avolio, 1993; Bass \& Steidlmeier,1999). These dimensions are briefly described as following:

Idealized influence: Includes identifying with the leader and the vision expressed by him, gaining a sense of common mission and purpose and being a role model for ethical behaviors.

Inspirational motivation: Includes declaring high expectations, using effort-oriented symbols and explaining significant objectives in simple ways.

Intellectual stimulation: Allows subordinates to question conventional behavior and thought patterns and create new perspectives on the problems that have also been presented previously.

Individualized consideration: The leader focuses on meeting the needs of each staff, acts as an individual, takes care of them, tries to develop their potential and guides them (Avolio, Bass \& Jung, 1999; Karip, 1998).

The first and most important qualification of a transformational leader is to have a vision. Vision is the mental picture of a desire and the potential situation of the organization in the future. Vision includes a specific mission and detailed objectives. The second qualification of a transformational leader is to understand human needs. Leaders have to know the complexity of human motivation so that they can get the support of followers. The third obligatory qualification of a transformational leader is to have strong personal values. The starting point of transformational leadership is the values and beliefs of the leader. The main purpose of the transformational influences of the leader is to change the values, beliefs, and attitudes of followers (Conger, 1999; Kuhnert \& Lewis, 1987). Transformational leaders take advantage of unchangeable universal values as a guide while formulating the ideal vision for the organization (Mendonca \& Kanungo, 2007) because vision arises as a result of values (Erdoğan, 2004; Özden, 2002). The moral principles and integrity of the leader bring legitimacy and credibility to vision (Mendonca, 2001). This allows identification with the leader and the vision expressed by him.

The changes experienced nowadays require schools to review and reorganize especially the education-training process, organization and management and school environment relations (Gümüşeli, 2001). In the face of these changes, the most appropriate leadership style for schools' restructuring initiatives is transformational leadership (Leithwood, 1992, 1994) because this leadership style aims innovation in organizations, devotes authority to teachers and supports them (Marks \& Printy, 2003). Leithwood, who adapted the transformational leadership models developed in out-of-school contexts to the school environment, determined transformational school leadership as six dimensions and ranked as following (Jantzi \& Leithwood, 1996; Leithwood, 1994; Leithwood \& Jantzi, 2005): (i) Determining and defining a vision: Defines, explains and develops new possibilities for the school and aims to inspire others with the vision of the future. (ii) Strengthening the acceptance of group objectives: It aims to develop cooperation between the members and to help working together to achieve the common goals. (iii) Providing individual support: It is the behavior aiming to be concerned with the needs and feelings of members and to show respect to them. (iv) Intellectual stimulation: Encourages members to re-examine some of 
the assumptions about the work they do and think about how they can fulfill it. (v) Creating an appropriate model: Shows exemplary behaviors for members to follow the values they have.(vi) High-performance expectations: Behaviors that show excellence, quality and high-performance expectations from the members.

\subsection{Innovation and Innovative School Management}

Innovation is to suggest and present new ideas successfully or to ensure the formation of something in a new way. It is to transform ideas into useful and applicable commercial products or services (Adair, 2008). According to Osborne and Brown (2005), innovation is putting new components into the public service in the form of new information, a new organization and/or new management or procedural skills. Conti, Coon, Lazenby and Herron (1996) define innovation as a successful implementation of creative ideas within an organization.

Innovation is a new or significantly improved product (goods or services) or process in applications within the business, in workplace organization or external relations, and the realization of a new marketing method or a new organizational method. The minimum requirement for innovation is that the product, process, marketing method or organizational method are new (or significantly improved) for the company. This includes the products, processes, and methods that companies have developed for the first time and that they have adapted from other companies or organizations (Oslo Manual, 2005).

Organizations need innovation management practices to be able to sustain their existence in the knowledge era in which it has now become a necessity to adapt to change and innovations quickly. In addition to sustaining their existence, it is extremely important for organizations to adapt knowledge to innovative processes so that they can gain a competitive advantage in the ever-changing conditions of global competition. The fact that organizations can adapt to the innovations in their surrounding and transform their environments with innovative activities simply depends on the fact that they organize their organizational structures based on innovation and can realize new product and service designs (Öğüt, Aygen and Demirsel, 2007). Innovation is a knowledge-based process and also the production and sharing this knowledge, and its transformation into new technology, products/services, and processes. However, it is also not possible to classify innovation areas only with technology, product, and service because it is observed that innovations are realized in a very wide range from social projects to education, from new sources of raw materials to markets and organizational structures (Uzkurt, 2008).

Innovation and continuous development are based on creativity and learning skills of the organization. It has become unavoidable for organizations to establish a successful innovation management process in organizations and to make it permanent. However, establishing a successful innovation process depends on a number of factors, not just one factor in organizations, because success varies depending on many factors. It can be considered that an innovative organizational culture, a leader who has understood the importance of innovation, and employees who have made innovation the most important work principle are the main factors among them. Leading organizations in their area of activity continuously create innovation and aim at new objectives with these innovations created. It is the duty of organizational leaders to put into practice this innovation created in every department of the organization and to create the conditions of its acceptance (Gülşen and Gökyer, 2010).

Organizational leaders need to be sufficient in many dimensions to be able to manage innovation. These dimensions can be categorized as Input Management, Innovation Strategy, Organizational Culture and Structure, and Project Management (Bülbül, 2012). Input Management includes resources required for innovation, and financial, human and physical resources (Adams et al., 2006). Organizational Culture and Structure have a key role in the innovation management as organizational culture affects all other factors and is also affected by the changes in other factors. Innovative organizational culture includes a shared vision, has an effect facilitating the innovations and allows the development of new ideas that can be exactly assessed (Adams et al., 2006). In addition to culture in the organization, structures and processes should also be appropriate to support innovative thinking and actions (Pollock, 2008). Project Management includes the process of selection, implementation, and evaluation of innovation projects (Adams et al., 2006).

School administrators who carry out innovation practices at school should encourage teachers to participate in decisions. School administrators should plan and implement the process of participation of teachers in decisions in a good way. When it is not well planned, teachers' time will be wasted. Teachers exposed to such a situation may develop attitudes which may negatively affect the innovation process along with their consideration that they are participating in an ineffective decision. Such a situation will negatively affect the organizational culture; especially new members will be disappointed. In this case, a negative socialization process will be experienced since a situation that should not happen has been exhibited. New members will be those who maintain the former culture by willingly or unwillingly learning the things that should not be done but done. For all these reasons, teachers' participation in decisions regarding innovation taken at school should be ensured, and their sensitivity areas should be extended (Özdemir and Cemaloğlu, 2000). 
Educational administrators should follow the changes in their own field and, on the other hand, should meet society's expectations from educational organizations as a result of the rapid changes. Nowadays, studies are also being carried out in the field of educational administration and school management as in many fields in Turkey and in other countries. These studies shed light on the theoretical and practical dimension of educational administration. Educational administrators should have a vision and mission. Administrators with the power to predict the future (vision) and mission (to create critical tasks) start from the facts of their organization. Such educational administrators also acknowledge that the vision can be realized in a strong school culture environment and by exhibiting leadership traits (Can, 2002).

School administrators should be aware of the need to undertake new roles in the face of globalization, information technology, scientific attitude and behavior, organizational learning and total quality management. The school principal is obliged to determine the mission and vision of the school, to develop the collaborative environment and the sense of governance at school, to think about "how to act" in order to achieve them as a whole and to create the school climate accordingly. All of these mean that the educational administrator of our age is responsible for organizing and sustaining his/her school as a "learning organization" to continuously improve the current situation (Okutan, 2003).

Based on this general framework, to reveal the relationship between the competence beliefs of school administrators on innovation management and their leadership behaviors can help to increase the educational quality of schools. It is thought by the researcher that the competence beliefs of school administrators on innovation management may increase as their leadership behaviors increase. Thus, it is possible to make deductions on the development of innovation management and transformational leadership behaviors. In this context, answers to the following questions were sought in this study:

1. From the viewpoint of teachers, what are school principals' competence beliefs on innovation management?

2. Is there a significant difference between school principals' competence beliefs on innovation management according to gender, type of school where they work, branch, educational status, age, and seniority?

3. From the viewpoint of teachers, what is the relationship between the competence beliefs of school administrators on innovation management and their leadership behaviors?

4. Is there a relationship between innovation management dimensions and leadership behaviors?

5. Is innovation management a predictor of leadership behaviors?

\section{DATA AND METHODOLOGY}

\subsection{Method}

This study that aims to determine the relationship between the competence beliefs of school administrators on innovation management and their leadership behaviors is a descriptive study in the relational screening model.

\subsection{Population and Sample}

Teachers working in Üsküdar district of Istanbul province in the 2015-2016 academic year constituted the population of the study. 320 teachers working at high schools, who participated in the application on a volunteer basis, whom the researcher reached and from whom he could receive permission, constituted the study group of the research.

\subsection{Data Collection Tools}

Two different measurement tools were used in this study. While the "school principals' leadership styles inventory", which was developed by Leithwood and Jantzi (1991) and adapted into Turkish by Sağnak (2010), was used to determine the transformational leadership style of school principals, the "innovation management at schools scale" developed by Bülbül (2012) was used to determine their competence beliefs on innovation management.

School principals' leadership styles inventory: The inventory consists of a total of 40 items, 29 of which define transformational leadership and 11 of which define transactional leadership. Regarding the sub-dimensions of transformational leadership, vision development/inspiring consists of 6 items, creating model consists of 4 items, developing group objectives consists of 5 items, providing support consists of 6 items, intellectual stimulation consists of 5 items, and having high expectations consists of 3 items. Regarding the sub-dimensions of transactional leadership, management by exceptions consists of 5 items, and conditional award consists of 6 items. The tool is a 5-point Likert-type scale in the form of strongly disagree (1), disagree (2), neutral (3), agree (4), totally agree (5).

Innovation management at schools scale: The teacher's form of the "innovation management at schools scale" developed by Bülbül (2012) was used as the second data collection tool in the study. The scale consists of four dimensions and 32 items. Regarding the dimensions of the scale, project management consists of 15 items, organizational culture and structure consist of 6 items, innovation strategy consists of 6 items and input management consists of 5 items. All the items 
in the scale are scored in the form of "1-Strongly Disagree", "2-Partially Agree", "3-Moderately Agree", "4- Strongly Agree", 5-Totally Agree". There is no reversely scored item in the scale. The total score can be obtained from the scale. The high score that can be taken from the whole scale and from its sub-dimensions indicates that teachers' perceptions of school administrators' innovation management competencies are at a high level.

\subsection{Analysis of the Data}

In the study, descriptive statistics such as the arithmetic mean and standard deviation of the answers given by teachers to the "Innovation Management at Schools Scale" were firstly calculated to reveal the competence beliefs of school administrators on innovation management. Then, whether the competence beliefs of school administrators on innovation management varied by some personal and professional characteristics was examined in the study. While the t-test was used in the comparisons made according to the teaching level and gender, the one-way analysis of variance (ANOVA) was used in the comparisons made according to seniority. Scheffe's test, one of multiple comparison tests, was used to determine the source of the difference for $F$ values that were found to be significant. The 0.05 significance level was taken as a basis in testing the differences between group mean scores. In the study, the following intervals were used in the evaluation of the weighted average scores: "1.00-1.79: Strongly disagree", "1.80-2.59: Partially agree", "2.60-3.39: Moderately agree", "3.40-4.19: Strongly Agree", "4.20-5.00: Totally Agree".

In conclusion, in the analysis of the data, the Pearson product-moment correlation coefficient was used to determine the relationship between the competence beliefs of school administrators on innovation management and their leadership behaviors. The simple linear regression analysis technique was used to determine whether transformational leadership behaviors predicted the innovation management.

\section{FINDINGS AND DISCUSSIONS}

\subsection{Descriptive Statistics}

The demographic informations of the survey participants such as gender, educational status, professional seniority and age are shown in the following tables.

Table 1: Descriptive Data of the Participants ( $N=320)$

\begin{tabular}{|c|c|c|}
\hline Variable & $\mathrm{N}$ & $\%$ \\
\hline \multicolumn{3}{|l|}{ Gender } \\
\hline Female & 207 & 64.7 \\
\hline Male & 113 & 35.3 \\
\hline \multicolumn{3}{|l|}{ Educational Status } \\
\hline Undergraduate & 232 & 72.5 \\
\hline Postgraduate & 83 & 25.9 \\
\hline Other & 5 & 1.6 \\
\hline \multicolumn{3}{|l|}{ Professional Seniority } \\
\hline $0-3$ Years & 32 & 10 \\
\hline 4-7 Years & 39 & 12.2 \\
\hline 8-11 Years & 57 & 17.8 \\
\hline $12-15$ Years & 45 & 14.1 \\
\hline $16-19$ Years & 47 & 14.7 \\
\hline 20 years and over & 100 & 31.3 \\
\hline \multicolumn{3}{|l|}{ Age } \\
\hline 40 Years and below & 176 & 55 \\
\hline 41 Years and above & 144 & 45 \\
\hline
\end{tabular}


The descriptive statistics of the teachers who participated in the study are presented in Table 1. Accordingly, 207 of them (64.7\%) were female, and 113 of them (35.3\%) were male teachers. When the educational status was examined, it was observed that 232 of the participants (72.5\%) had undergraduate education, and 83 of them (25.9\%) had post-graduate education. According to the professional seniority, it is observed that the numbers of teachers in different educational seniorities are close to each other. Finally, it is observed that 176 of the participants (55\%) were under 40 years of age and 144 of them (45\%) were aged 40 and below.

\subsection{Path Analysis}

The path analysis was performed to determine the predictive effect of the competence beliefs of school administrators on innovation management on the leadership behaviors of principals. Innovation management was defined as the function of four different sub-dimensions. These sub-dimensions were defined as Input Management, Innovation Strategy, Organizational Culture and Structure and Project Management. Leadership sub-dimensions were defined by the transactional leadership and transformational leadership sub-dimensions. The findings of the path analysis performed are presented in Figure 1.

\section{Figure 1: Path Analysis Showing the Relationships Between Innovation Management Competences and} Leadership Behaviors

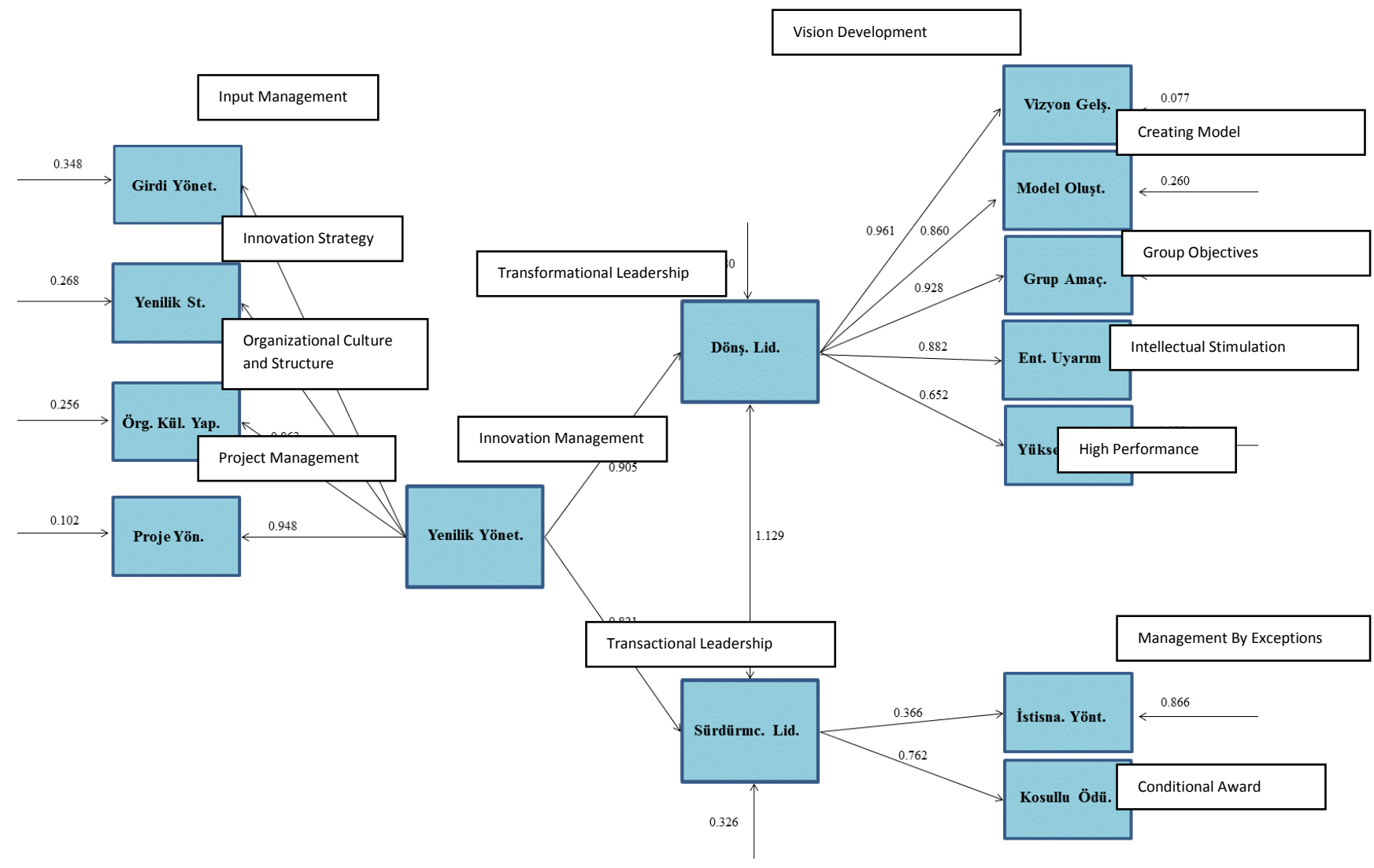

In the model created, it was envisaged that school principals' innovation management competencies would have predictive effects on transactional leadership and transformational leadership and that there would be an interaction between transactional leadership and transformational leadership. The fit of this model was tested using the Mlus 6.12 statistical package program. According to the findings obtained, this model created was found to be well adapted to the data $\left(\chi^{2}=\right.$ 128.55, $\mathrm{df}=41, \mathrm{p}=0.000$; RMSEA = 0.066-0.098; $\mathrm{CFI}=974 ; \mathrm{TLI}=0.965 ; \mathrm{SRMR}=0.033$ ).

It was also found out that all of the path coefficients in Figure 1 were significant. It was observed that innovation management competencies consisting of four different sub-dimensions had significant predictive effects on transactional leadership behaviors consisting of two sub-dimensions and on transactional management sub-dimensions consisting of five sub-dimensions. 


\subsection{Other Findings}

In this part of the research, the tables of descriptive statistics are shown according to the answers given by the teachers on the Innovation Management Belief Scale and on the sub dimensions of it.

In addition, the statistical tables of the analysis of teachers' innovation management competence beliefs by some variables such as gender, age, seniority and educational status are shown.

Table 2: Descriptive Statistics of the Innovation Management Belief Scale

\begin{tabular}{|c|c|c|c|c|}
\hline & $\overline{\mathrm{X}}_{\min .}$ & $\overline{\mathrm{X}}_{\max }$ & $\overline{\mathrm{X}}$ & $X_{\text {sd }}$ \\
\hline Input Management & 5 & 25 & 17.37 & 4.88 \\
\hline Innovation Strategy & 6 & 64 & 21.88 & 6.38 \\
\hline Organizational Culture and Structure & 6 & 64 & 22.21 & 6.49 \\
\hline Project management & 15 & 98 & 54.42 & 14.52 \\
\hline
\end{tabular}

The descriptive statistics of the Innovation Management Belief scale are presented in Table 2. Accordingly, the scores obtained by teachers in the Input Management sub-dimension vary between 5 and $25\left(\bar{X}=17.37, X_{s d}=4.88\right)$. The scores obtained by teachers in the Innovation Strategy sub-dimension vary between 6 and $64\left(\bar{X}=21.88, X_{s d}=6.38\right)$. The scores obtained by teachers in the Organizational Culture and Structure sub-dimension vary between 6 and $64\left(\overline{\mathrm{X}}=22.21, \mathrm{X}_{s d}=\right.$ 4.49). The scores obtained by teachers in the Project Management sub-dimension vary between 15 and $98\left(\overline{\mathrm{X}}=54.42, \mathrm{X}_{s d}=\right.$ 14.52).

Table 3: Examination of the Competence Beliefs of Teachers on Innovation Management According to the Gender Variable

\begin{tabular}{|c|c|c|c|c|c|c|c|}
\hline & $t$ & $\mathrm{df}$ & $p$ & & $\mathrm{~N}$ & $\overline{\mathrm{X}}$ & $X_{s d}$ \\
\hline \multirow[t]{2}{*}{ Input Management } & 0.791 & 318 & 0.429 & Female & 207 & 17.53 & 4.71 \\
\hline & & & & Male & 113 & 17.08 & 5.17 \\
\hline \multirow[t]{2}{*}{ Innovation Strategy } & 0.805 & 318 & 0.421 & Female & 207 & 22.10 & 6.64 \\
\hline & & & & Male & 113 & 21.49 & 5.87 \\
\hline \multirow{3}{*}{$\begin{array}{l}\text { Organizational Culture and } \\
\text { Structure }\end{array}$} & & & & & & & \\
\hline & 0.144 & 318 & 0.885 & Female & 207 & 22.25 & 6.07 \\
\hline & & & & Male & 113 & 22.14 & 7.23 \\
\hline \multirow[t]{2}{*}{ Project Management } & 0.598 & 318 & 0.550 & Female & 207 & 54.78 & 14.49 \\
\hline & & & & Male & 113 & 53.76 & 14.60 \\
\hline
\end{tabular}

The independent samples t-test was performed to examine whether the Competence Beliefs of Teachers on Innovation Management varied by the gender variable. The findings obtained are presented in Table 3. According to the findings obtained, all of the sub-dimension scores did not differ significantly between female and male teachers.

Table 4: Examination of the Competence Beliefs of Teachers on Innovation Management According to the Age Variable

\begin{tabular}{|c|c|c|c|c|c|c|c|}
\hline & $t$ & df & $p$ & & $\mathrm{~N}$ & $\overline{\mathrm{X}}$ & $\mathrm{X}_{\mathrm{SC}}$ \\
\hline \multirow[t]{2}{*}{ Input Management } & 0.749 & 318 & 0.454 & 40 Years and below & 17.55 & 4.50 & 0.749 \\
\hline & & & & 41 Years and above & 17.14 & 5.30 & \\
\hline \multirow[t]{2}{*}{ Innovation Strategy } & 0.288 & 318 & 0.774 & 40 Years and below & 21.97 & 6.04 & 0.288 \\
\hline & & & & 41 Years and above & 21.77 & 6.78 & \\
\hline
\end{tabular}




\begin{tabular}{|c|c|c|c|c|c|c|c|}
\hline $\begin{array}{l}\text { Organizational Culture } \\
\text { Structure }\end{array}$ & 0.045 & 318 & 0.964 & 40 Years and below & 22.22 & 6.91 & $0.045^{*}$ \\
\hline & & & & 41 Years and above & 22.19 & 5.96 & \\
\hline \multirow[t]{2}{*}{ Project Management } & 0.435 & 318 & 0.664 & 40 Years and below & 54.73 & 14.44 & 0.435 \\
\hline & & & & 41 Years and above & 54.02 & 14.63 & \\
\hline
\end{tabular}

The independent samples t-test was performed to examine whether the Competence Beliefs of Teachers on Innovation Management varied by the age variable. The findings obtained are presented in Table 4. According to the findings obtained, the Input Management, Innovation Strategy and Project Management sub-dimension scores did not differ significantly between teachers in different age groups. On the other hand, it was found out that the Organizational Culture and Structure sub-dimension scores were in favor of teachers aged 40 and older $(p<0.05)$.

Table 5: Examination of the Competence Beliefs of Teachers on Innovation Management According to the Seniority Variable

\begin{tabular}{|c|c|c|c|c|c|c|}
\hline & & Squares $\mathrm{T}$. & $\mathrm{df}$ & Squares 0. & $\mathrm{~F}$ & $p$ \\
\hline \multirow[t]{3}{*}{ Input Management } & Intergroup & 111.69 & 5 & 22.34 & 0.938 & 0.457 \\
\hline & Intragroup & 7479.05 & 314 & 23.82 & & \\
\hline & Total & 7590.75 & 319 & & & \\
\hline \multirow[t]{3}{*}{ Innovation Strategy } & Intergroup & 226.53 & 5 & 45.30 & 1.115 & 0.352 \\
\hline & Intragroup & 12756.19 & 314 & 40.62 & & \\
\hline & Total & 12982.72 & 319 & & & \\
\hline \multicolumn{7}{|l|}{ Organizational Culture and } \\
\hline \multirow{2}{*}{ Structure } & Intragroup & 13168.16 & 314 & 41.94 & & \\
\hline & Total & 13441.55 & 319 & & & \\
\hline \multirow[t]{3}{*}{ Project Management } & Intergroup & 924.964 & 5 & 184.99 & 0.876 & 0.497 \\
\hline & Intragroup & 66296.92 & 314 & 211.14 & & \\
\hline & Total & 67221.89 & 319 & & & \\
\hline
\end{tabular}

The independent samples t-test was performed to examine whether the Competence Beliefs of Teachers on Innovation Management varied by the seniority variable. The findings obtained are presented in Table 5. According to the findings obtained, all of the sub-dimension scores did not differ significantly between teachers with different seniority levels.

Table 6: Examination of the Competence Beliefs of Teachers on Innovation Management According to the Educational Status Variable

\begin{tabular}{|c|c|c|c|c|c|c|c|}
\hline & $t$ & $\mathrm{df}$ & $p$ & & $\mathrm{~N}$ & $\overline{\mathrm{X}}$ & $X_{s d}$ \\
\hline \multirow[t]{2}{*}{ Input Management } & 0.447 & 313 & 0.655 & Undergraduate & 232 & 17.49 & 4.94 \\
\hline & & & & Postgraduate & 83 & 17.21 & 4.66 \\
\hline \multirow[t]{2}{*}{ Innovation Strategy } & 0.275 & 313 & 0.784 & Undergraduate & 232 & 21.99 & 6.53 \\
\hline & & & & Postgraduate & 83 & 21.77 & 5.99 \\
\hline \multirow{3}{*}{$\begin{array}{l}\text { Organizational Culture and } \\
\text { Structure }\end{array}$} & & & & & & & \\
\hline & 0.867 & 313 & 0.387 & Undergraduate & 232 & 22.47 & 6.59 \\
\hline & & & & Postgraduate & 83 & 21.75 & 6.17 \\
\hline \multirow[t]{2}{*}{ Project Management } & 0.4 & 313 & 0.689 & Undergraduate & 232 & 54.73 & 14.33 \\
\hline & & & & Postgraduate & 83 & 53.98 & 15.12 \\
\hline
\end{tabular}

The independent samples t-test was performed to examine whether the Competence Beliefs of Teachers on Innovation Management varied by the educational status variable. The findings obtained are presented in Table 6 . According to the 
findings obtained, all of the sub-dimension scores did not differ significantly between teachers with different educational levels.

\section{CONCLUSION}

It was observed that the competence beliefs of teachers on innovation management did not vary significantly between female and male teachers by the gender variable, and they also did not vary significantly by the age variable; on the other hand, the Corporate Culture and Structure sub-dimension scores were in favor of teachers who were 40 years old and older. Furthermore, it was observed that they did not vary significantly between teachers with different seniority levels by the seniority variable and they did not vary significantly between teachers with different levels of education by the status of education variable.

Furthermore, it was also observed that teachers' perceptions of the innovation management competencies of school administrators were the highest in the project management sub-dimension, were moderate in the innovation strategy and organizational culture-structure sub-dimensions and low in the input management sub-dimension.

\section{REFERENCES}

Adair, J. (2008). Yenilikçi liderlik [Innovative leadership]. İstanbul: Babıali Kültür.

Adams, R. Bessant, J., \& Phelps, R. (2006). Innovation management measurement: A review. International Journal of Management Reviews, 8 (1) 21-47.

Ata, E. (2015). Okul yöneticilerinin özyeterlik inançları ile etkili okul liderliği arasındaki ilişki (Yayımlanmamış doktora tezi) [The relationship between the self-efficacy beliefs of school administrators and effective school leadership (Unpublished doctoral thesis)]. Gazi Üniversitesi, Ankara.

Avolio, B. J., Bass, B. M., \& Jung, D. I. (1999). Re-examination the components of transformational and transactional leadership using the multifactor leadership questionnaire. Journal of Occupational and Organizational Psychology, 72, 441-462.

Bass, B. M., \& Avolio, B. J. (1993). Transformational leadership and organizational culture. Public Administration Quarterly, 17, $112-121$.

Bass, B. M., \& Steidlmeier, P. (1999). Ethics, character, and authentic transformational leadership behavior. Leadership Quarterly, 10(2), 181-217.

Bass, B. M. (1999). Two decades of research and development in transformational leadership. European Journal of Work and Organizational Psychology, 8(1), 9-32.

Bolman, L. G., \& Deal, T. E. (1991). Reframing organizations. San Francisco: Jossey-Bass Publishers.

Burns, J. M. (1978). Leadership. New York: Harper \& Row Publishers.

Bush, T., \& Glover, D. (2014). School leadership models: What do we know? School Leadership \& Management, 34(5), 553-571. doi:10.1080/13632434.2014.928680

Bülbül, T. (2012). Okullarda yenilik yönetimi ölçeği'nin geliştirilmesi: Geçerlik ve güvenirlik çalışması [Development of the innovation management at schools scale: Validity and reliability study]. Kuram ve Uygulamada Eğitim Bilimleri, 12 (1), $157-175$.

Can, N. (2002). Değişim sürecinde eğitim yönetimi [Educational administration in the process of change]. Milli Eğitim Dergisi, 155-156, 8998.

Ciulla, J. B. (1995). Leadership ethics: Mapping the territory. Journal of Business Ethics,5, 5-28.

Conger, J. A. (1999). Charismatic and transformational leadership in organizations: An insider's perspective on these developing stream of research. Leadership Quarterly, 10(2), 145-179.

Conti, R., Coon, H., Lazenby, J., \& Herron, M. (1996). Assessing the work environment for creativity. Academy of Management Journal, 39 (5), 1154-1184

Gunter, H. (2004). Labels and labelling in the field of educational leadership. Discourse: Studies in the Cultural Politics of Education, 25(1), 21-41. doi:10.1080/0159630042000178464

Gülşen, C. ve Gökyer, N. (2010, Mayıs). Illköğretimde yeniliklerin uygulanmasını etkileyen olası etkenler. 9. Ulusal Sınıf Öğretmenliği Eğitimi Sempozyumunda sunulan bildiri, Fırat Üniversitesi, Elazığ [Possible factors affecting the application of innovations in elementary education. Paper presented at the 9th National Classroom Teaching Education Symposium, Fırat University, Elazığ].

Gümüşeli, A. İ. (2001). Çağdaş okul müdürünün liderlik alanları [Leadership areas of the contemporary school principal]. Kuram ve Uygulamada Eğitim Yönetimi, 28, 531-548.

Harris, A., Day, C., \& Hadfield, M. (2003). Teachers' perspectives on effective school leadership. Teachers and Teaching Theory and Practice, 9(1), 66-77. 
Karip, E. (1998). Dönüşümcü liderlik [Transformational leadership]. Kuram ve Uygulamada Eğitim Yönetimi, 4(16), $443-465$.

Krüger, M. (2009). The big five of school leadership competences in the Netherlands. School Leadership \& Management, 29(2), $109-127$. doi:10.1080/13632430902775418

Kuhnert, K. W., \& Lewis, P. (1987). Transactional and transformational leadership: A constructive/developmental analysis. Academy of Management Journal, 12(4), 648-657.

Leithwood, K., \& Jantzi, D. (2005). A review of transformational school leadership research 1996-2005. Leadership and Policy in Schools, 4, 177-199.

Leithwood, K. (1992). The move toward transformational leadership. Educational Leadership, 49(5), 8-12.

Leithwood, K. (1994). Leadership for school restructuring. Educational Administrative Quarterly, 30(4), 498-518.

Leithwood, K. A., \& Montgomery, D. J. (1982). The role of the elementary school principal in program improvement. Review Of Educational Research, 52 (3), 309-339.

Leithwood, K. A., \& Reihl, C. (2005). What do we already know about educational leadership? Firestone, W. A. and Reihl C. (eds). A new agenda for research in educational leadership. New York: Teacher Collage Press.

Leithwood, K. A., Jantzi, D., \& Steinbach, R. (1999). Changing leadership for changing times. Buckingham, UK: Open University Press.

Marks, H. M., \& Printy, S. M. (2003). Principal leadership and school performance: An integration of transformational and instructional leadership. Educational Administration Quarterly, 39(3), 370-397.

Marzano, R. J., Waters, T., \& McNulty, B. A. (2005). School leadership that works: From research to results. USA, VA: ASCD.

Mendonca, M., \& Kanungo, R. N. (2007). Ethical leadership. New York: Open University Press.

Mendonca, M. (2001). Preparing for ethical leadership in organizations. Canadian Journal of Administrative Sciences, 18(4), 266-276.

Murphy, J., Elliott, S. N., Goldring, E. B., \& Porter, A. C. (2010). Leaders for productive schools. In International Encyclopedia of Education (pp. 746-751). Elsevier Ltd. doi: 10.1016/B978-0-08-044894-7.00461-9

Okutan, M. (2003). Okul müdürlerinin idari davranışları [Administrative behaviors of school principals]. Milli Eğitim Dergisi, 157, $226-236$.

Osborne S. P., \& Brown K. (2005). Managing change and innovation in public service organizations. Londra: Routledge.

Oslo Kılavuzu. (2005). Yenilik verilerinin toplanması ve uygulanması için ilkeler (3. Baskı) [Principles for the collection and application of innovation data (3rd edition)]. Ankara: Ekonomik İşbirliği ve Kalkınma Örgütü Avrupa Birliği İstatistik Ofisi, OECD ve Eurostat Ortak

Öğüt, A., Aygen, S. ve Demirsel, M. T. (2007). Personel güçlendirme inovasyonu hızlandırır mı? Antalya ili beş yıldızlı konaklama işletmelerine yönelik görgül bir araştırma [Does employee empowerment accelerate innovation? An empirical study on five-star accommodation businesses in Antalya province]. Selçuk Üniversitesi i.i.BF Dergisi. Yerel Ekonomiler Özel Sayısı, 163-172.

Özdemir, S. ve Cemaloğlu, N. (2000). Eğitimde örgütsel yenileşme ve karara katılma [Organizational innovation in education and agreeing with the decision]. Milli Ĕgitim Dergisi,146, 54-63.

Pollock, K. (2008). The four pillars of innovation: An elementary school perspective. The Innovation Journal: The Public Sector Innovation Journal, 13 (2).

Robinson, V. M. J., Lloyd, C. A., \& Rowe, K. J. (2008). The impact of leadership on student outcomes: An analysis of the differential effects of leadership types. Educational Administration Quarterly, 44(5), 635-674. doi:10.1177/0013161X08321509.

Robinson, V. M., Hohepa, M., \& Lloyd, C. (2007). School leadership and student outcomes: Identifying what works and why (Vol. 41). Melbourne: Australian Council for Educational Leaders.

Sağnak, M. (2010). Dönüşümcü okul liderliği ile etik iklim arasındaki ilişki [The relationship between transformational school leadership and ethical climate]. Kuram ve Uygulamada Ĕgitim Bilimleri, 10(2), 1113-1152.

Sergiovanni, T. J. (1984). Leadership and excellence in schooling. Educational leadership, 41(5), 4-13.

Sergiovanni, T. J. (1996). Leadership for the schoolhouse: How is it different? Why is it important?. Jossey-Bass, Inc. Publishers.

Sergiovanni, T. J. (2001). The principalship: A reflective practice perspective. Boston : Pearson/Allyn and Bacon.

Uzkurt, C. (2008). Yenilik yönetimi ve yenilikçi örgüt kültürü [Innovation management and innovative organizational culture]. İstanbul: Beta Yayım.

Waters, T., Marzano, R. J., \& McNulty, B. (2003). Balanced leadership: what 30 years of research tells us about the effect of leadership on student achievement. A working paper. Retrieved from http://files.eric.ed.gov/fulltext/ED481972.pdf

Wilmore, E. L. (2002). Principal leadership: Applying the new educational leadership constituent council (ELCC) standards. Thousand Oaks, CA: Corwin Press. 